\title{
A Wheelbarrow Full of Frogs: Understanding Portfolio Management for Agile Projects
}

\author{
Isabelle Smeekes \\ University of Amsterdam \\ ismeekes@yahoo.com
}

\author{
Hans Borgman \\ University of Amsterdam \\ h.p.borgman@uva.nl
}

\author{
Hauke Heier \\ Accenture \\ hauke.heier@accenture.com
}

\begin{abstract}
Organizations increasingly embrace agile approaches for IT projects, replacing rigid formal stage-gate control by flexible output-orientation. This challenges established program or portfolio management approaches that largely rely on consolidated (stage-gate) project metrics. Based on seven case studies of large Dutch organizations we explore these challenges and the organizational responses towards a new approach to portfolio management for agile projects. Data-collection is guided by four propositions derived from control theory and portfolio management literature. Our findings show that portfolio management adapts to agile projects by performing fewer and less strict process controls, by modifying the budget controls and by shifting from IT project/program control to business outcome control, with an increased focus on business value.
\end{abstract}

\section{Introduction}

Agile methods stress the importance of continuous improvement of working products with limited documentation and little formal planning. The Agile Manifesto [1], the foundation for agile methods, values response to change over following a plan. In addition, the Agile methodology emphasizes that teams should be autonomous, and management must learn to stimulate this through support rather than by checking for milestones, and trusting teams to get the job done [2]. Agile approaches are credited with many advantages at the project level, including an increased project efficiency and overall stakeholder satisfaction [3] as well as increased project member satisfaction, as they perceive agile to be more compatible to their actual working practices [4]. However, those responsible to manage a collection of projects at the portfolio level may feel a loss of overview and control as agile's dynamic and autonomous way of working is not compatible with widely accepted portfolio management approaches such as COBIT [5] that stress formal documentation and stage-gate planning.

The purpose of this study is to explore how organizations that embrace agile approaches at project level deal with the challenges this poses to control at the portfolio level.

Investigating this issue is of relevance both academically as well as managerially. The notion of control in organizations 'embracing agile' [6] has almost exclusively been explored on the level of the individual project or team [7] [8]. Portfolio management is however of great importance: as shown by Weill and Broadbent, well-governed IT portfolios lead to superior firm performance, with an increased ROA of $30 \%$ [9]. A mismatch between data requirements of established portfolio management methods or practices on the one hand, and available metrics at project level on the other, will likely result in portfolio management that is less transparent and more subjective [10]. This sentiment is echoed by practitioners: at a Scaling agile event in Amsterdam in March 2017, many upper level managers expressed their frustrations and concerns regarding project control within their agile portfolios [11]. The difficulty regarding control for portfolio management becomes more pressing as firms are seeking ways to expand agile practices while keeping portfolios aligned with organizational goals and simultaneously controlling risks and costs [12]. This leads to our research question: What are the challenges and responses to control in portfolio management for agile organizations?

Our study employs an exploratory multiple case study design, reflecting the limited extant literature in this area as well as the need to study this relatively new phenomenon in its context. The seven case studies include general descriptive and contextual information, as well as observations and interviews at both project and portfolio level. Data collection is guided by a set of propositions derived from control theory as well as portfolio management literature 
(section 2). Section 3 describes the methods in more detail, followed by an overview of the cases (section 4 ) and the cross-case analysis (section 5). Section 6 discusses our findings and implications for practice as well as future research.

\section{Literature review}

In order to explore the challenges to portfolio management in agile projects and methods, we first compare control mechanisms in traditional and agile environments. We then move to (traditional) portfolio management, demonstrating its shortcomings in order to support agile methods. This leads us to derive four working propositions that guide the data collection and analysis process.

\subsection{Control: traditional vs. agile}

When observing control in organizations, Mahadevan, Ketinger and Meservy define control by means of "mechanisms" permitting an organization to proceed towards its goals, both at project as well as portfolio level [13]. Traditionally, they state, hierarchy and structure are the core mechanisms, aided by structured stage-gate or waterfall practices. With agile approaches these mechanisms are largely replaced by autonomy in development teams, customer involvement and flexible "facilitative control practices" [14]. Kirsch [15] adds a focus on the role of management and their relationship with employees as they guide individuals to work according to an established strategy and to ultimately attain necessary objectives. Maruping, Venkatesh and Agarwal [16] build on this, applying Kirsch' perspective to agile project-level control. They argue that, under circumstances "of high requirements change," the use of agile methodology and control modes that stimulate autonomous teams are essential and effective in realizing improved project quality. As the autonomous nature of agile teams helps achieving success, the relationship between the teams and those involved in portfolio management must stimulate this through the use of proper mechanisms [2].

Alongside the importance of objectives and the role of management, varying methods of control are investigated in studies concerning agile and organizational control; typically these are derived from control theory, the "study of the mechanisms that can be used to achieve organizational objectives" [17].

Originally, control theory was developed by Ouchi in his influential studies, as he described four types of control: output control, behavioral control, clan control and self-control [18]. These types of control are further classified into formal and informal control; informal control including self and clan control and formal control including behavior and outcome-based control. The formal manner of measurement, through behavioral or process controls and output controls, is often employed in organizations to monitor project development. Harris, Collins and Hevner [17], looking specifically at flexible software development, propose a new emergent outcome control concept, describing how scope boundaries and ongoing feedback can steer development rather than evaluate results.

Process controls influence and monitor the behavior of the employees or team members and how they accomplish their goals, while output controls directly influence and monitor the outcome and what teams should accomplish [19], [20]. Traditional firms often incorporate process controls through the agency of high levels of documentation and monitoring throughout the development process. However, Bonner et al. claim that innovation is often stagnated due to the implementation of process controls [21].

As agile is said to stimulate innovation through working products and reduced documentation, the focus of control may shift in nature and therefore, control mechanisms must adjust accordingly [1].

\subsection{Portfolio management}

Traditionally, portfolio managers attempt to achieve a balance between four goals of: "maximizing the financial value of the portfolio, linking the portfolio to strategy, balancing it on relevant dimensions, and ensuring that the total number of ongoing activities is feasible" [3]. Typically, the goals in the areas of finance, strategy, stability, and achievability are conflicting for portfolio managers as they struggle to accomplish these by means of: distinguishing potential projects, ranking project priority, allocation, balancing and, finally, evaluating [22], [19]. These traditional practices of portfolio management are further aided through the incorporation of both process and output controls [23].

In portfolio management for agile projects, the underlying project practices are altered, as a team based structure with flexible projects, frequent reviews and evaluations is advocated [19]. This implies that portfolio managers need to increase flexibility and continuous reprioritization, as opposed to the fixed and traditional periodic project review. The adjustment in role and control of portfolio management is due to the independent and flexible nature of agile teams and the reduction in documentation, hence, traditional portfolio control methods are no longer sufficient for agile teams [24]. 
When shifting from traditional to an agile organization, portfolio management should consider the following aspects of the agile working methods: the iterative nature of the projects which are continuously producing working prototypes, faster pace short sprints, the incorporation of feedback from customers, and within teams, the daily updates and increased verbal communication [25], [26]. As a result, management must accept less measurements through phase gate processes and an increased emphasis on working prototypes [1]. Evidently, this demonstrates once again that portfolio management must adjust their control based on the agile implementations in their organization.

\subsection{Portfolio control in the agile organization}

A number of studies have established that traditional portfolio management methods and controls clash with agile ways of working [14], [19], [24]. As projects and agile teams become increasingly flexible and self-managed, portfolio managers perform less process control tasks and must adjust their influential role as controller. In addition to this, agile teams rarely report the interim status of work in progress and emphasize communication and presentation of (partially) finished products in the form of demos [27], [28]. This is in line with the Agile Manifesto which stresses that working software is the primary measure of progress, and that communication supersedes reporting as well as monitoring for autonomous teams [1]. In conjunction with Bello and Gilliand's [19] work, stating that process controls include traditional monitoring activities and the use of guidelines, this leads to the first proposition:

Proposition 1: Fewer and less strict process controls are performed when firms are transitioning into agile organizations.

As the focus on process control in agile working methods is proposed to occur less, other traditional methods of control such as budget controls have high potential to transform as well. The flexibility of agile teams and continuous prioritization of user stories and initiatives causes project managers to face conflicts when negotiating budget to fund their agile team(s) [29]. Therefore, Drury-Grogan's work proposes to discuss budget regularly after each agile iteration [30]. For portfolio management, budget is one of the main processes when managing and selecting projects and measuring outcome [31].

Agile methods can no longer be supported by traditional budgeting methods as the traditional manner of defining a budget for a fixed set of projects per year must become more dynamic in order to facilitate this new way of working [32], [33]. The latter results in logical grounds for the following proposition:

Proposition 2: Budget controls within portfolio management are modified when a firm transitions into an agile organization.

Rather than monitoring through process controls and traditional budget controls, for agile methods it is more appropriate for portfolio managers to focus on business outcomes and customer value [34]. This is evident as agile is fixed on business output and the customer through improving the time to market, incorporating customer feedback, and promoting continuous improvement [35].

In addition, Alahyari et al.'s work suggests that agile methods are more focused on creating value as opposed to other methods [36]. This would imply that business outcome controls are emphasized as opposed to process controls in agile organizations [16], [37]. Consequently, providing a rational foundation to form the proposition below:

Proposition 3: The portfolio management shifts from process control to business outcome control when transforming into an agile organization.

Outcomes are often regarded as the link between the customer end of the business and control of the agile team's underlying development processes [38]. Understanding the overall organizational outcome objectives can also aid in the recognition of which agile methods to implement in the firm's way of working [39].

Outcome success measurement is central and for agile projects, primarily related to business value [16], [37]. Furthermore, as business focus and control is said to increase, IT focus control decreases [13]. This leads to the suggestion that as the final business related results become central, IT has more of an enabling role for agile projects. In Mahadevan et al.'s article, the authors claim that there is an increased focus on the business function as opposed to information system function when agile is implemented [13]. At the same time, the shift to business value allows for more control concerning outcomes and goals as opposed to processes [16], [37]. Likewise, firms are increasingly aiming to produce value for customers and the organization by incorporating requirements in order to realize these values [40]. These findings provide support for the following proposition:

Proposition 4: The portfolio management shifts their focus from IT outcomes to business outcomes when transforming into an agile organization.

The focus on business output is further supported by Santos and Oliveira who stress that teams, with the assistance of the agile ways of working, should focus on the value for the project in business and for the client, which is ultimately the goal to be achieved [41]. 


\section{Research method}

The multiple case study approach has been determined to uncover patterns and to strengthen the reliability and validity of this research [42]. The seven firms studied are service firms with headquarters in The Netherlands and have had agile methods implemented into their previously traditional organization. Each case study contains two interviews; one with an individual involved in the portfolio management and one with a product owner or Scrum master. Both interviewees are active in the same agile portfolio, which is essential for the data reliability and consistency of this study. Furthermore, the interviews are semi-structured and the interview guideline has been generated based on propositions created in section two. Each interview was conducted at the firm's headquarters with one interviewee and one interviewer at the interviewee's convenience. The interviews were 45 to 60 minutes; recorded, transcribed and analyzed. Each case, composed of two interviews and observations, was analyzed per proposition with a description of the firm's stance supported by illustrative quotes. This method of analysis is displayed in Table 1 which exemplifies the analysis of case 2 for the first proposition.

Table 1. Analysis Case 2 Proposition 1

\begin{tabular}{|c|c|c|}
\hline \multirow{4}{*}{\begin{tabular}{|l|} 
Proposition \\
Process control \\
occurs less by \\
portfolio management \\
when a firm \\
transitions into an \\
Agile organization. \\
\end{tabular}} & Stance \& position of firm & Quotes \\
\hline & \multirow{3}{*}{$\begin{array}{l}\text { Portfolio managers create clear goals } \\
\text { that teams need to work on by using } \\
\text { roadmaps. They focus less on process } \\
\text { controls and "how" they get there. } \\
\text { Furthermore, the responsibility is } \\
\text { being shifted to the team level. } \\
\text { Portfolio managers are updated every } \\
3 \text { weeks through demos. There is an } \\
\text { increased focus on vision and goals } \\
\text { as opposed to process. }\end{array}$} & $\begin{array}{l}\text { "We set goals for our department and we } \\
\text { want to monitor our own (teams) goals to } \\
\text { see if we are on track." }\end{array}$ \\
\hline & & $\begin{array}{l}\text { "So, my (portfolio management) control is } \\
\text { less on how they are doing it but more on } \\
\text { the goals that we are achieving." }\end{array}$ \\
\hline & & $\begin{array}{l}\text { "I think it's easier to maintain the control } \\
\text { because it's not my control. It's... we all } \\
\text { have common goals. So it's not mine. It's } \\
\text { the goals of the train (teams). So it's } \\
\text { something that we have in common and we } \\
\text { all agreed upon." }\end{array}$ \\
\hline
\end{tabular}

After having visited the firm's headquarters, additional observations were noted based on the following traits for each firm: hierarchy, portfolio management governance and atmosphere. This in turn strengthened the construct validity as each firm's environment and the employees interviewed were taken into account.

In section four the seven cases are summarized and in section five they are examined in a cross case analysis. This analysis is performed in order to uncover patterns, challenges and relevant factors to provide valuable insights on control for portfolio management in agile organizations.

\section{Cases}

In tables 2 and 3 we provide general company characteristics for each case study, as well as specific details of their agile experiences, portfolio management and IT governance arrangements, gathered from observations and interview transcripts. The cross-case analysis (section 5) elaborates on additional consequences and compares the findings per proposition which are in turn illustrated by exemplary quotations.

Table 2. Case study overview: governance arrangements

\begin{tabular}{|c|c|c|c|}
\hline Case & Hierarchy & $\begin{array}{l}\text { Portfolio management } \\
\text { Governance }\end{array}$ & $\begin{array}{l}\text { HQ } \\
\text { Atmosphere }\end{array}$ \\
\hline $\begin{array}{l}\text { 1: Air } \\
\text { France } \\
\text { KLM }\end{array}$ & $\begin{array}{l}\text { Traditional and } \\
\text { vertical, however } \\
\text { is transforming to } \\
\text { a flatter structure }\end{array}$ & $\begin{array}{l}\text { One portfolio manager } \\
\text { for each business unit. }\end{array}$ & $\begin{array}{l}\text { Formal and } \\
\text { traditional. } \\
\text { Digital domain } \\
\text { is lively. }\end{array}$ \\
\hline $\begin{array}{l}2: \\
\text { Achmea }\end{array}$ & $\begin{array}{l}\text { Quite a horizontal } \\
\text { hierarchical } \\
\text { structure compared } \\
\text { to the cases } \\
\text { studied }\end{array}$ & $\begin{array}{l}\text { One information } \\
\text { manager for long term } \\
\text { portfolio management } \\
\text { and one product } \\
\text { manager for the short } \\
\text { term per department } \\
\end{array}$ & $\begin{array}{l}\text { Social and } \\
\text { open. } \\
\text { Management is } \\
\text { hangs quite low } \\
\text { in the } \\
\text { organization. }\end{array}$ \\
\hline $\begin{array}{l}\text { 3: } \\
\text { AEGON }\end{array}$ & $\begin{array}{l}\text { Vertical however, } \\
\text { there is a new } \\
\text { structure with } \\
\text { value owners } \\
\text { responsible for } \\
\text { teams. }\end{array}$ & $\begin{array}{l}\text { The portfolio } \\
\text { management role is } \\
\text { taken up by an upper } \\
\text { management board who } \\
\text { stays in contact with } \\
\text { value owners. }\end{array}$ & $\begin{array}{l}\text { Innovative, } \\
\text { lively and } \\
\text { corporate. }\end{array}$ \\
\hline $\begin{array}{l}4: \\
\text { Schiphol } \\
\text { Group }\end{array}$ & $\begin{array}{l}\text { Is transitioning } \\
\text { from slightly } \\
\text { vertical to } \\
\text { horizontal }\end{array}$ & $\begin{array}{l}\text { A portfolio team is } \\
\text { composed of a portfolio } \\
\text { manager, Agile coach, } \\
\text { product owners and } \\
\text { developers. }\end{array}$ & $\begin{array}{l}\text { Open, friendly } \\
\text { and flexible. } \\
\text { Startup-like in } \\
\text { the digital } \\
\text { domain. }\end{array}$ \\
\hline $\begin{array}{l}5: \mathrm{ABN} \\
\text { AMRO }\end{array}$ & $\begin{array}{l}\text { Vertical however } \\
\text { interviewees state } \\
\text { that it is becoming } \\
\text { flatter. }\end{array}$ & $\begin{array}{l}\text { Departments have } \\
\text { multiple grids } \\
\text { containing products. A } \\
\text { grid owner is the } \\
\text { portfolio manager. }\end{array}$ & $\begin{array}{l}\text { Formal and } \\
\text { corporate. } \\
\text { Some } \\
\text { development } \\
\text { teams work on } \\
\text { the trading } \\
\text { floor. }\end{array}$ \\
\hline $\begin{array}{l}\text { 6: ING } \\
\text { Group }\end{array}$ & $\begin{array}{l}\text { Vertical Hierarchy } \\
\text { which has become } \\
\text { flatter in the Agile } \\
\text { areas. }\end{array}$ & $\begin{array}{l}\text { One full time portfolio } \\
\text { manager per unit of } \\
\text { each department. }\end{array}$ & $\begin{array}{l}\text { Corporate yet } \\
\text { dynamic. } \\
\text { Department } \\
\text { had an open } \\
\text { atmosphere. }\end{array}$ \\
\hline $\begin{array}{l}7: \\
\text { Jumbo }\end{array}$ & $\begin{array}{l}\text { Traditional family } \\
\text { firm with a vertical } \\
\text { hierarchy }\end{array}$ & $\begin{array}{l}\text { One portfolio manager } \\
\text { leading the portfolio } \\
\text { board per department }\end{array}$ & $\begin{array}{l}\text { Formal, } \\
\text { structured and } \\
\text { calm. }\end{array}$ \\
\hline
\end{tabular}

\section{Cross case analysis}

A cross case comparison is performed in which each proposition is examined and compared in order to generate conclusions [43]. This analysis is supported by extant literature and direct quotations from interviewees in order to increase the reliability and objectivity of the findings [43].

\subsection{P1: Process control}

This section highlights that firms transitioning to agile, and particularly the portfolio management, no longer focus on how teams develop their epics or projects. Primarily, the focus lies on what they are developing 
Table 3. Case study overview: agile experience

\begin{tabular}{|l|l|l|l|l|l|l|l|}
\hline \multicolumn{1}{|c|}{ Case } & Industry & $\begin{array}{c}\text { Firm } \\
\text { age (yr.) }\end{array}$ & $\begin{array}{c}\text { Start date agile } \\
\text { implementation }\end{array}$ & $\begin{array}{c}\text { Agility } \\
\text { Firm (\%) }\end{array}$ & $\begin{array}{c}\text { Portfolio } \\
\text { Department }\end{array}$ & $\begin{array}{c}\text { Agility } \\
\text { portfolio (\%) }\end{array}$ & $\begin{array}{c}\text { Agile } \\
\text { method }\end{array}$ \\
\hline $\begin{array}{l}\text { 1: KLM } \\
\text { Air France }\end{array}$ & Aviation & 97 & $\begin{array}{l}2005 \text { Scrum teams \& } \\
2016 \text { portfolio }\end{array}$ & $30 \%$ & Digital & $100 \%$ & $\begin{array}{l}\text { Scrum } \\
\text { Kanban }\end{array}$ \\
\hline 2: Achmea & $\begin{array}{l}\text { Financial } \\
\text { services }\end{array}$ & 22 & $\begin{array}{l}2015 / 2016 \text { scrum teams } \\
\text { and portfolio }\end{array}$ & $50 \%$ & Private Damages & $80-90 \%$ & Scrum \\
\hline 3: AEGON & $\begin{array}{l}\text { Financial } \\
\text { services }\end{array}$ & 34 & $\begin{array}{l}2012 / 2013 \text { scrum teams } \\
\text { and portfolio }\end{array}$ & $30-50 \%$ & Web and Mobile & $80-100 \%$ & $\begin{array}{l}\text { Scrum } \\
\text { Kanban } \\
\text { Lean }\end{array}$ \\
\hline $\begin{array}{l}\text { 4: Schiphol } \\
\text { Group }\end{array}$ & Aviation & 101 & $\begin{array}{l}\text { 2014 Scrum teams and } \\
\text { portfolio }\end{array}$ & $25 \%$ & $\begin{array}{l}\text { Digital solution } \\
\text { center }\end{array}$ & $100 \%$ & $\begin{array}{l}\text { Scrum } \\
\text { Kanban }\end{array}$ \\
\hline $\begin{array}{l}\text { 5: ABN } \\
\text { AMRO }\end{array}$ & Banking & 26 & $\begin{array}{l}\text { 2016 scrum teams \& } \\
\text { 2017 portfolio }\end{array}$ & $20-25 \%$ & Global markets & $100 \%$ & Scrum \\
\hline $\begin{array}{l}\text { 6: ING } \\
\text { Group }\end{array}$ & Banking & 26 & $\begin{array}{l}2015 \text { scrum teams and } \\
\text { portfolio }\end{array}$ & $30-40 \%$ & $\begin{array}{l}\text { Wholesale: } \\
\text { Client service } \\
\text { delivery }\end{array}$ & $100 \%$ & Scrum \\
\hline $\begin{array}{l}\text { 7: Jumbo } \\
\text { Retail }\end{array}$ & 96 & $\begin{array}{l}2015 \text { scrum teams \& } \\
\text { 2017 portfolio }\end{array}$ & $20 \%$ & ICT & $60 \%$ & Scrum \\
\hline
\end{tabular}

and the business value generated. In case 2, concerning Achmea, one of the interviewees clearly states that his "control is less on how they are doing it, but more on the goals that we are achieving." Air France KLM, ING and ABN AMRO emphasize the decreased focus on process as well.

In case 5, for instance, a product owner of ABN AMRO states: "I really don't report to anyone." In addition, at ING (case 6), the product owner refers to the relationship between the portfolio manager and the teams, as the portfolio managers "can't tell them (the teams) how to do it." Likewise, at Air France KLM, the portfolio level interviewee stated that they "try to do no reporting, only real time views on what we are doing." These "real time views" mentioned are in the form of demos after each sprint. Indeed, these cases correspond to the Agile Manifesto by conveying the importance of working software and communication opposed to high levels of documentation and reporting [1]. Traditional waterfall methods, such as Prince2, focus on process controls, hence, traditional firms transitioning to agile should reduce the use of process controls and increase their focus on demos and communication [27].

Cases 3, 4 and 7, of AEGON, Schiphol and Jumbo, are distinctive due to their differing agile implementation phases.

Exploring the concept of agile, Jumbo is in an early stage of the implementation process and outsources the majority of its IT projects. Although one Jumbo interviewee states: "You do not have to plan anything" .... "you deliver what you can deliver;" they continue to report regularly with updates including scope, budget and quality as well as red, yellow and green ratings. Previously, firms such as ABN AMRO, used these weekly "red, yellow and green reporting" methods, whereas in agile, they simply perform demos after every sprint.

As the methodology of agile is implemented throughout the firm, AEGON and Schiphol realize that it is essential to oversee their teams in a more efficient way. To stimulate efficiency and transparency, AEGON, Achmea and Schiphol have created their own KPIs which teams share with portfolio management. Schiphol uses their "Objective Key Results" while Achmea and AEGON employ a dashboard with relevant KPIs.

Often, the portfolio managers of firms such as ABN AMRO mention their consideration of dashboards and KPIs to employ in the future. Some firms, such as Achmea, employ team dashboards to keep track of their internal team performance. Nevertheless, these dashboards have potential to be shared with portfolio management, allowing them to assist teams when necessary. When transforming into an agile organization, firms focus on minimal reporting and documentation. However, in order maintain an overview of the portfolio, a dashboard to monitor progress has potential to aid portfolio managers.

At the same time, the portfolio level interviewee at Achmea underlines that it is necessary to keep physical communication between portfolio level and the team level: "we have some dashboards, but it is not ... you stay in control by visiting the teams, to speak with the teams, to have an open door if there are problems."

This leads to another point of consideration highlighted by Achmea, Schiphol, ABN AMRO and ING, which is the notion of trust. The portfolio manager must have the appropriate role in the development process and should stimulate the 
autonomy of the teams by exhibiting that they "trust the teams." Furthermore, one of the interviewees of Air France KLM, highlights the new role portfolio managers should embody as "chief enabler" whilst they give up their "illusion of control."

Through the use of open communication and dashboards for additional assistance, trust can be increased and portfolio managers reduce their process controls to stimulate their firm's agile way of working.

\subsection{P2: Budget control}

Undeniably, organizations transitioning to agile realize the need for the rest of their organization's processes to transform to agile as well. The budgeting process is interconnected with process controls and is used to monitor many agile projects today [32]. In the cases explored, most of the firms are experiencing changes in the budgeting process. Firms further in agile implementation, such as KLM, Achmea, AEGON, ING and Schiphol, clearly emphasize that their budgeting processes are now fixated on funding teams as opposed to projects. The following examples illustrate this:

Air France KLM has clearly made the transition from project funding to team funding, as one of the interviewees states: "we ask for budget based on the full department, instead of a budget per project. That's the biggest change."

Similarly, Schiphol's interviewee, responsible for portfolio management, expresses: "Then I will fund the team. That team will work on an important thing like way finding or waiting times and they will decide what's most important to build at that moment."

Also responsible for portfolio management, ING's interviewee, indicates how funding is allocated by department budget per team as opposed to value chains budget per project. This is conveyed by the following quote: "[the developers] can book the hours they work on our budget accounts,". Furthermore, this same interviewee refers to the value chain funding per initiative as he states: "It's like the old fashioned way because they have a priority that they really want to stimulate."

According to Lohan, Conboy and Lang, agile methods can no longer be supported by traditional budgeting methods [33]. The traditional method of budgeting entailed yearly in depth business cases for multiple projects and requests for budgets based on these business cases. Conversely, in the agile way of working and in most of the cases explored, the budget is determined per quarter or year per department, making it more flexible [32].
The funding in the agile organizations studied are based on teams, as the projects are determined through the continuous prioritization process. Consequentially, less detailed budget proposals or business cases are required before the budgeting process as the projects, according to ABN AMRO, "are not set in stone." Though the firms further in agile have already transformed their budgeting process, the interviewees continued to convey the need for more flexibility.

After having funded teams for some time now, Schiphol's portfolio manager is contemplating new ways to organize and to potentially fund "purposes" as opposed to teams. This is due to the team's demand to continuously fill their backlogs in their particular realm of expertise, while purposes have a broader range of products. Similarly, AEGON is currently working with value owners in their "Next" way of agile working.

An alternative future implementation AEGON is considering is the creation of groups of specialists which teams are comprised of. The reason for this is to stimulate flexibility and to uncover the optimum combination of individuals. This is illustrated as the portfolio management level interviewee discusses the future way of working at AEGON where "you will still have teams. But ideally it becomes a lot more flexible and people are a lot more open, also to switch from different groups etc."

Often, firms, such as ING and Jumbo, outsource IT related projects. Hence, resulting in the budget of their department to first be distributed to third parties to subsequently be divided between their department's teams in the agile manner. This is underlined in the quote: "in a couple of projects the team is working scrum and the other developments are with external firms and not using the scrum teams. "Due to the large number of outsourced projects, Jumbo is not able to fully shift to an agile budgeting process, although they do employ quarterly checkups on prioritization and the agile "weigh the shortest job first" (WSJF) method.

As agile firms transform their budget process from project funding to team funding or purpose funding, detailed upfront business cases are no longer common place and light weight value based decisions are prominent.

\subsection{P3: Outcome control}

This section illustrates that business outcomes are progressively important to measure for project success and control to satisfy the customer end of the business and the control of the underlying development processes [38]. The focus on outcome is evident in the cases studied as stakeholder involvement in the form feedback loops and focus on user related outcomes 
increases [32]. Furthermore, the emphasis on goals are suggested to increase because, as suggested in proposition 1 , the process control use decreases.

The importance of output control and goal achievement is exemplified in case 2 regarding Achmea: "My control is less on how they are doing it but more on the goals that we are achieving." The manager in the product owner role at Achmea continuously stressed the importance of clear goals and open communication within his teams and stakeholders.

AEGON, similar to Achmea, is goal oriented as teams record 6 output and progress related metrics in their dashboards. Portfolio management views these dashboards when necessary, allowing them to asses if they need to aid teams or product owners. Likewise, Moran states in his work that output metrics are valuable ways to assess these agile projects [24]. The six metrics presented on the dashboard are as follows: the speed of value creation, quality of value, the functional capacity evaluation (who is working etc.), cost, employee happiness, and the bucket and fix-it list. The bucket and fix-it list is a list containing resources teams need, for example: a sum of money, time, or a specialist.

Besides the dashboard, AEGON and ING's agile development teams communicate openly through meetings with product owners regarding the goals and road maps as opposed to traditional documentation. These meetings and dashboards are purely to ensure that product owners and their teams deliver the necessary outcomes. The portfolio level interviewee at AEGON declares the shift of focus to output in the following example: "It's really about creating output and not steering on the input but measuring the output." Comparably, both the interviewees from Achmea and ABN AMRO state that the focus is on the "what" as opposed to the "how."

On the other hand, having started implementing agile at a later moment in time (2017), Jumbo relies more heavily on process controls. Jumbo's documentation and routine meetings between product owners and the portfolio manager have caused the importance of process controls to remain present and is apparent in the following statement: "I always look at the process" ... "Because the outcome is the result of the process." Although Jumbo is slightly more process oriented, they have centered their attention toward "business value (outcome) when launching projects."

In agile organizations, the focus on goals and outcomes related to the customer stimulate the overall business value that firms are operating to satisfy. KLM highlighted their importance for shared goals and clarity in the following statement: "The whole system is having a goal. So, we are, in the end, having a better linked strategy to the execution, with all noses in the same direction, delivering as a collective, more for the customer." Similarly, Moran states that team performance is regularly measured by customer satisfaction which is often the goal [24].

The notion of goals returns as Schiphol's "Objective Key Results (OKRs)" are goals each team works towards for every sprint. The OKRs are a stepping stone toward what the portfolio manager and product owner determine will be the optimal output and business value of the products developed.

Our findings underscore a trend focusing on goals and outcome as opposed to how development processes are performed. In turn suggesting a shift to take place from process controls to outcome controls for portfolio managers in agile firms [37]. This finding is further supported by the concept of emergent outcome control discussed in section 2.1, highlighting how continuous feedback based on outcome assists in steering flexible development [17].

\subsection{P4: Business outcomes}

Our findings show that the type of outcome focused on in the Agile paradigm is related to business value.

In the portfolio process, most firms apply the "weigh the shortest job first" (WSJF) method in order to prioritize projects, characterized by the highest amount of business value and the shortest amount of time and effort for development. At the same time, many firms such as Schiphol, ABN AMRO and ING play poker with the business value of their epics and user stories to determine priority. One of the interviewees, a product owner at Schiphol, affirmed: "They poker them on business value." Poker allows the teams and portfolio management to determine which epics or user stories have the most business value and will benefit the firm most in the future by means of a discussion. After this, the epics or the smaller user stories are prioritized which aids to bring forth a minimum viable product (MVP). In turn, the MVP is developed after every sprint, and, if time allows, more value can be added. At Achmea, they continuously develop MVPs for each epic and move on to the next. Only once additions or extra user stories are said to have business value, they will be added to their backlog for development.

WSJF, Poker and MVP are prioritization processes performed by portfolio management stressing the importance of business value based on what the customer wants and needs in the products developed. Since the implementation of agile, Achmea, like AEGON, started to examine the results in the form of 
business value generated, innovation, agility, the traditional budget, enjoyment and planning accuracy. Planning accuracy refers to how accurate teams are able to predict their time to market. This too is an element closely affiliated to business value, as prediction aids prioritization which stimulates value generation. These differing aspects of examining outcome are related to the team's work and are shared with portfolio managers when necessary or through the transparent dashboards.

Goals and output pertaining to business value are ubiquitous at Achmea, ING and ABN AMRO as roadmaps are created based on business value and goals are clearly broken down for each product owner. This is often referred to as a "Vision," determined primarily by the product owner, however the portfolio manager predominantly establishes the 3-5-year plan regarding which epics should be considered in the long run. The focus on business output is further supported by Santos and Oliveira who stress that teams, with the assistance of the agile ways of working, should focus on the value for the project within the business and for the client, which is ultimately the goal to be achieved [41].

Due to the new manner of continuous prioritization, firms are able to shift the focus to items that have a greater amount of business value and can benefit the customer in the long run. KLM's product owner articulates the flexibility of agile and the ability to improve business value in the following quote:

"Being able to adapt your plan really quickly. It doesn't mean we don't plan anymore. But you have more room to be agile, to include things that have high priority to come high up on the list. We release more often. So, we bring more value to the customer somewhere."

This example illustrates that as the process controls are reduced, there is more business value focus, which consequentially leads to faster and more valuable business outcomes.

Furthermore, whilst business output is increasing, ABN AMRO and Jumbo clearly state that IT is perceived as an "enabler" as the "boundaries between ICT and business are fading." Likewise, business focused control is suggested to increase as IT focused control decreases [13]. According to Mahadevan et al., this is due to the increase of business focus visibility that agile practices have for IT development [13].

Largely, the cases examined have provided evidence to support that portfolio management shifts their focus from IT outcomes to business outcomes when transforming into an agile organization. The importance of business value is significant in agile methods and is therefore proposed to be the desired outcome [36]. As customer involvement and business value are suggested to develop significance and process controls occur less, business outcomes are central to portfolio managers while IT is considered an enabling tool to produce this value.

\section{Discussion and future research}

Our findings support the propositions that portfolio management adapts to agile projects by performing fewer and less strict process controls, by modifying the budget controls and by shifting from IT project/program control to business outcome control, with an increased focus on business value. This addresses the research question: What are the challenges and responses to control in portfolio management for agile organizations?

Although we found only limited direct support for the first proposition regarding process controls, all firms clearly expressed their reduction of documentation in their development processes, offering strong indirect support. Propositions two, three and four received stronger direct support, with the cases not only offering evidence and examples, but also valuable nuances. This, together with the explored literature, forms a good basis to suggest further exploration and testing of these propositions in future research.

The implications of our results are twofold. First, portfolio management shifts their focal point from process control to outcome control by emphasizing business value and outcomes. To add to this implication, the budget controls are adjusted to focus on autonomous teams, and in some cases, values instead of detailed upfront business cases.

The second implication underlines transparent and trusted communication through meetings, demos and, occasionally, elements such as live dashboards. It can be argued that the presence of these elements is essential at all levels of organizations, especially in firms implementing agile methods. This is in line with Stettina and Hörz's work as they describe the culture shift of agile organizations which encourages cooperation based on interactive communication, transparency and trust [20]. Similarly, Cram and Brohman highlight the need for communication in order to generate meaningful business outcomes [14].

This implication suggests a role change for portfolio management, as they must support and stimulate the agile way of working. Although this aspect was not explicitly addressed in our propositions, our data suggest that this is an important element in the response of firms. Using the words of an interviewee in the Air France KLM case, the role of the portfolio manager becomes more of "a chief enabler," as opposed to the traditional monitoring 
manager. This role of chief enabler, encouraging trust, communication and focusing on business value outcome, is viewed as essential and, in line with our literature study, should stimulate the autonomous teams and business value in agile portfolios [2], [9], [11]. We expect this 'enabling' aspect to be a fruitful avenue for further exploration.

As next step, the propositions as well as the enabling role of portfolio management should be further studied in order to determine appropriate operational measures and to ultimately quantify these findings. In addition, multiple levels of the firm, such as the c-level executives, should be included as interviewees to enrich our understanding of agile methodologies across all levels of organizations. This last aspect is particularly important with reference to organizational politics, as fewer 'objective' formal controls may give more space for more subjective processes [10]. Furthermore, as organizational adoption of agile methods at project level continues to grow, and as portfolio management practices continue to mature, more (and more mature) field studies and possibly more quantitative studies should become feasible. Likewise, longitudinal studies that aim to understand the dynamics and changes in attitude during diverse stages of the agile portfolio maturity will likely add more to our understanding of the challenges, responses and underlying forces and motivations concerning portfolio management for agile organizations.

\section{References}

[1] M. Fowler and J. Highsmith, "The agile manifesto," Softw. Dev., vol. 9, no. August, pp. 28-35, 2001.

[2] R. Hekkala, M. Stein, and M. Rossi, "Challenges in Transitioning to an Agile Way of Working," 2017.

[3] P. Serrador and J. K. Pinto, "Does Agile work? - A quantitative analysis of agile project success," Int. J. Proj. Manag., vol. 33, no. 5, pp. 1040-1051, 2015.

[4] S. Overhage and S. Schlauderer, "Investigating the long-term acceptance of agile methodologies: An empirical study of developer perceptions in Scrum projects," in Proceedings of the Annual Hawaii International Conference on System Sciences, 2011, pp. 5452-5461.

[5] S. De Haes, W. Van Grembergen, and R. S. Debreceny, "COBIT 5 and Enterprise Governance of Information Technology: Building Blocks and Research Opportunities,” J. Inf. Syst., vol. 27, no. 1, pp. 307-324, Jun. 2013.
[6] D. K. Rigby, J. Sutherland, H. Takeuchi, T. S. John, and H. Org, "How to master the process that's transforming management," Harv. Bus. Rev., 2016.

[7] C. J. Stettina and J. Hörz, “Agile portfolio management: An empirical perspective on the practice in use," Int. J. Proj. Manag., vol. 33, no. 1, pp. 140-152, 2015.

[8] K. Rautiainen, J. Von Schantz, and J. Vähäniitty, "Supporting scaling agile with portfolio management: Case Paf.com," Proc. Annu. Hawaii Int. Conf. Syst. Sci., no. 1, 2011.

[9] P. Weill and J. W. Ross, IT governance : how top performers manage IT decision rights for superior results. Harvard Business Press, 2004.

[10] F. G. Neves, H. P. Borgman, and H. Heier, "Success Lies in the Eye of the Beholder: The Mismatch Between Perceived and Real IT Project Management Performance," in 49th Hawaii Conference on System Sciences, 2016, pp. 58785887.

[11] N. Groen, "SAFe Leadership Day hosted by BlinkLane consulting \& Gladwell Academy." Amsterdam, The Netherlands, 2017.

[12] L. Kappelman, E. McLean, and V. Johnson, "The 2016 SIM IT Trends Study," MIS Q. Exec. A1, vol. 16, no. 1, pp. 1-10, 2017.

[13] L. Mahadevan, W. J. Ketinger, and T. O. Meservy, "Running on hybrid: Control changes when introducing an agile methodology in a traditional 'waterfall' system development environment," Commun. Assoc. Inf. Syst., vol. 36, pp. 77-103, 2015.

[14] W. A. Cram and M. K. Brohman, "Beyond Modes: A New Typology of ISD Control," Icis, p. Paper 94, 2010.

[15] L. J. Kirsch, "The Management of Complex Tasks in Organizations: Controlling the Systems Development Process," Organ. Sci., vol. 7, no. 1, pp. 1-21, 1996.

[16] L. M. Maruping, V. Venkatesh, and R. Agarwal, "A Control Theory Perspective on Agile Methodology Use and Changing User Requirements," Inf. Syst. Res., vol. 20, no. 3, pp. 377-399, 2009.

[17] M. L. Harris, R. W. Collins, and A. R. Hevner, "Control of flexible software development under uncertainty," Inf. Syst. Res., vol. 20, no. 3, pp. 400-419, 2009.

[18] W. G. Ouchi, "A Conceptual Framework for the Design of Organizational Control Mechanisms A CONCEPTUAL FRAMEWORK FOR THE DESIGN OF ORGANIZATION," Source Manag. Sci., vol. 25, no. 9, pp. 833-848, 1979. 
[19] D. C. Bello and D. I. Gilliland, "The Effect of Output Controls, Process Controls, and Flexibility on Export Channel Performance.," J. Mark., vol. 61, no. 1, pp. 22-38, 1997.

[20] A. Tiwana and M. Keil, "Control in Internal and Outsourced Software Projects," J. Manag. Inf. Syst., vol. 26, no. 3, pp. 9-44, 2010.

[21] J. M. Bonner, R. Ruekert, and O. C. Walker, "Upper management control of new product development projects and project performance," Journal of Product Innovation Management, vol. 19, no. 3. pp. 233-245, 2002.

[22] L. Kester, A. Griffin, E. J. Hultink, and K. Lauche, "Exploring portfolio decision-making processes," J. Prod.Innov. Manag., vol. 28, no. 5, pp. 641661, 2011.

[23] R. Mueller, M. Martinsuo, and T. Blomquist, "Project Portfolio Control and Portfolio management Performance in Different Contexts," Proj. Manag. J., pp. 28-42, 2008.

[24] A. Moran, Managing agile: Strategy, implementation, organisation and people. 2015.

[25] J. S. Saltz, "The need for new processes, methodologies and tools to support big data teams and improve big data project effectiveness," Proc. - 2015 IEEE Int. Conf. Big Data, IEEE Big Data 2015, pp. 2066-2071, 2015.

[26] D. Bishop and A. Deokar, "Toward an Understanding of Preference for Agile Software Development Methods from a Personality Theory Perspective," 2014 47th Hawaii Int. Conf. Syst. Sci.,pp. 4749-4758, 2014.

[27] P. Gregory, L. Barroca, H. Sharp, A. Deshpande, and K. Taylor, "The challenges that challenge: Engaging with agile practitioners' concerns," Inf. Softw. Technol., 2016.

[28] E. Miranda and P. Bourque, "Agile monitoring using the line of balance," J. Syst. Softw., vol. 83, no. 7, pp. 1205-1215, 2010.

[29] Y. Shastri, R. Hoda, and R. Amor, "Understanding the Roles of the Manager in Agile Project Management," Proc. 10th Innov. Softw. Eng. Conf. - ISEC '17, no. March, pp. 45-55, 2017.

[30] M. L. Drury-Grogan, "Performance on agile teams: Relating iteration objectives and critical decisions to project management success factors," Inf. Softw. Technol., vol. 56, no. 5, pp. 506-515, 2014.

[31] A. Badewi, "The impact of project management (PM) and benefits management (BM) practices on project success: Towards developing a project benefits governance framework," Int. J. Proj. Manag., vol. 34, no. 4, pp. 761-778, 2016.
[32] L. Cao, K. Mohan, B. Ramesh, and S. Sarkar, "Adapting funding processes for agile IT projects: an empirical investigation," Eur. J. Inf. Syst., vol. 22, no. 2, pp. 191-205, 2013.

[33] G. Lohan, K. Conboy, and M. Lang, "Beyond Budgeting and Agile Software Development: A Conceptual Framework for the Performance Management of Agile Software Development Teams," Icis-Rp, pp. 1-10, 2010.

[34] E. C. Conforto, F. Salum, D. C. Amaral, S. L. Da Silva, and L. F. M. De Almeida, "Can agile project management be adopted by industries other than software development?," Proj. Manag. J., 2014.

[35] J. Highsmith, "What Is Agile Software Development?," J. Def. Softw. Eng., vol. 15, no. 10, pp. 4-9, 2002.

[36] Z. Racheva, M. Daneva, and K. Sikkel, "Value creation by agile projects: Methodology or mystery?," Lect. Notes Bus. Inf. Process., vol. 32 LNBIP, pp. 141-155, 2009.

[37] S. R. Nidumolu and M. R. Subramani, "The matrix of control: Combining process and structure approaches to managing software development," J. Manag. Inf. Syst., vol. 20, no. 3, pp. 159-196, 2003.

[38] A. J. Sohi, M. Hertogh, M. Bosch-Rekveldt, and R. Blom, "Does lean \& agile project management help coping with project complexity?," Procedia Social Behav. Sci., vol. 226, pp. 252-259, 2016.

[39] J. F. Tripp and D. J. Armstrong, "Exploring the relationship between organizational adoption motives and the tailoring of agile methods," Proc. Annu. Hawaii Int. Conf. Syst. Sci., pp. 4799-4806, 2014.

[40] S. Alam, S. Nazir, S. Asim, and D. Amr, "Impact and Challenges of Requirement Engineering in Agile Methodologies: A Systematic Review," Int. J. Adv. Comput. Sci. Appl., vol. 8, no. 4, 2017.

[41] L. Santos, S. Ronaldo, and B. Oliveira, "A Framework with Agile Practices for Implementation of Project Portfolio Management Process," no. c, pp. 191-195, 2016.

[42] K. M. Eisenhardt and M. E. Graebner, "Theory Building from Cases: Opportunities and Challenges," Acad. Manag. J., vol. 50, no. 1, pp. 25-32, 2007.

[43] K. M. Eisenhardt, "Building Theories from Case Study Research.," Acad. Manag. Rev., vol. 14, no. 4, pp. 532-550, 1989. 